This is a draft chapter/article. The final version will be available in Planetary Boundaries and International Law edited by Duncan French and Louis Kotzé forthcoming 2020/21, Edward Elgar Publishing Ltd.

The material cannot be used for any other purpose without further permission of the publisher, and is for private use only.

\title{
Changing Role of Law-Making in Responding to Planetary Boundaries?
}

Giovanna M. Frisso and Elizabeth A. Kirk

\section{$\underline{\text { Abstract }}$}

Legal discourse focuses on the potential to improve law to prevent breaches of the planetary boundaries and on the adoption of new measures to give the Earth system time to recover from human actions. That analysis, however, tends to rest on the assumption that we can modify our existing laws in ways that will prompt individuals and States to modify their behaviour so as to reduce the risk of breaching the planetary boundaries. In this chapter we examine the roots of this approach and present alternative approaches which may prove more fruitful. In particular, we propose a move within law to focus on responsibilities more than on rights, and to embracing approaches within indigenous and other cultures which also focus on responsibilities.

Key words: Planetary boundaries, international environmental law, rights, responsibilities, challenges

\section{Introduction}

Legal discourse on the potential of law to help ensure human behaviour does not breach the planetary boundaries tends to focus on areas in which the law can be improved to prevent further reductions in the carrying capacity of the Earth caused by human actions. New measures are proposed to give the Earth time to recover from human activities. This discourse rests on the assumption that it is possible to tweak existing international and national laws, and through that nudge States and individuals into behaving in ways that do not threaten the Earth system's planetary boundaries. The result is that laws are adopted, for example, to reduce the use of certain single use plastics, ${ }^{1}$ but no laws are adopted to stop the use of oil based plastics completely. ${ }^{2}$ Similarly, while treaties exist to place limits on certain activities they appear ineffective. For example, while the Convention on International Trade in Endangered Species of Wild Fauna and Flora (CITES) exists to limit trade in endangered species, ${ }^{3}$ more and more species are added to the list of those that are endangered, either in treaty agreements or in scientific papers. ${ }^{4}$

\footnotetext{
${ }^{1}$ See for example the Single Use Carrier Bags Charges (England) Order 2015.

${ }^{2}$ Kirk, E.A. and Popattanachai, N., (2018) 'Marine plastics: fragmentation, effectiveness and legitimacy in international law-making’ 27 RECIEL 222-233.

${ }^{3}$ Convention on International Trade in Endangered Species of Wild Fauna and Flora 1973 (1976) 993 UNTS

243 entered into force 1 July 1975.

${ }^{4}$ Justin Worland "There Are More Endangered Species than Ever: Here's what to know on endangered species day" Time 18 May 2017.
} 
This is a draft chapter/article. The final version will be available in Planetary Boundaries and International Law edited by Duncan French and Louis Kotzé forthcoming 2020/21, Edward Elgar Publishing Ltd.

The material cannot be used for any other purpose without further permission of the publisher, and is for private use only.

In examining these discourses, we highlight their limits as a framework for safeguarding the Earth's planetary boundaries and explore possible alternatives. In particular, we focus on the need to embrace an understanding of the relationship between humans and our environment, that is found in a variety of cultures which are often overlooked at present. Such a move risks being undermined by the autopoietic nature of law and so we propose that, in order to minimise this risk, the focus of legal discourse must move from rights to responsibilities.

\section{The Roots of Current Approaches}

A number of international treaties have been adopted which are directly relevant to preventing breaches of the planetary boundaries. For instance, threats to stratospheric ozone are addressed most clearly through the Ozone Convention, ${ }^{5}$ and climate change is addressed through the United Nations Framework Convention on Climate Change (UNFCCC). ${ }^{6}$ Both conventions are also relevant to addressing aerosol loading, which is also governed by agreements such as the Convention on Long-range transboundary Air Pollution. ${ }^{7}$ Threats to the biosphere and ecosystems are addressed primarily through the Convention on Biological Diversity (CBD), ${ }^{8}$ and through treaties which focus on particular ecosystems (such as the 1980 Convention for the Conservation of Antarctic Marine Living Resources), ${ }^{9}$ or on particular aspects of ecosystem management (such as the 1995 Fish Stocks Agreement). ${ }^{10}$ Chemical pollution is addressed through a series of treaties focussed on particular types of pollutant such as the Stockholm Convention on Persistent Organic Pollutants, ${ }^{11}$ the Minamata Convention ${ }^{12}$ addressing pollution from mercury, and treaties addressing pollutants in particular regions, such as the Convention for the Protection of the Marine Environment of

\footnotetext{
${ }^{5} 1985$ Vienna Convention for the Protection of the Ozone Layer (adopted 22 March 1985, entered into force 22 September 1988) 1513 UNTS 293.

${ }^{6} 1992$ United Nations Framework Convention on Climate Change (adopted 9 May 1992, entered into force 21 March 1994)1771 UNTS 107 4. See, respectively Du Toit, chapter 12; and Verschuuren, chapter 15 in this volume.

71979 Convention on Long-range Transboundary Air Pollution (adopted 13 November 1979, entered into force 16 March 1983) 1302 UNTS 217.

81992 Convention on Biological Diversity (adopted 5 June 1992, entered into force 29 December 1993) 1760 UNTS 79.

${ }^{9}$ Convention on the Conservation of Antarctic Marine Living Resources, (adopted 5 May 1980, entered into force 7 April 1982) 1329 UNTS 47.

${ }^{10}$ Agreement for the Implementation of the Provisions of the United Nations Convention on the Law of the Sea of 10 December 1982 Relating to the Conservation and Management of Straddling Fish Stocks and Highly Migratory Fish Stocks, (adopted 4 August 1995, entered into force 11 December 2001) 2167 UNTS 3. See, also Trouwborst and Somsen, chapter 13 in this volume.

112001 Stockholm Convention on Persistent Organic Pollutants (adopted 22 May 2001, entered into force 17 May 2004) 2256 UNTS 119.

122013 Minamata Convention on Mercury (adopted 10 October 2013, entered into force 16 August 2017) UNTS treaty number No. 54669 (No volume number has yet been allocated.)
} 
This is a draft chapter/article. The final version will be available in Planetary Boundaries and International Law edited by Duncan French and Louis Kotzé forthcoming 2020/21, Edward Elgar Publishing Ltd.

The material cannot be used for any other purpose without further permission of the publisher, and is for private use only.

the North-East Atlantic (OSPAR Convention) ${ }^{13}$ which tackles marine pollution in the NorthEast Atlantic. Certain planetary boundaries are less obviously addressed by international agreements. Ocean acidification is, for example, indirectly addressed through the United Nations Convention on the Law of the Sea (UNCLOS), ${ }^{14}$ the UNFCCC and the CBD. Nitrogen and phosphorous flows are also addressed indirectly through UNCLOS, but more directly through regional seas agreements such as the OSPAR Convention and the Convention for the Protection of the Marine Environment of the North-East. ${ }^{15}$ Land system change is addressed through the Convention on Desertification, ${ }^{16}$ and through soft law instruments on forest management, ${ }^{17}$ but there is little directly addressing issues such as increasing urbanisation. ${ }^{18}$

Besides the obvious gaps in coverage, in terms of preventing breaches of the planetary boundaries four key issues arise with these treaties. The first relates to the monitoring and enforcement of State obligations and the second to the nature of the obligations found within treaties. Both issues arise because each treaty is developed from the assumption that States have sovereignty over their territory and thus have the rights to use that territory and the resources in it as they wish, provided they do not cause harm to the territory, interests or rights of other States. ${ }^{19}$ The third issue is that our laws and legal systems are largely based on the idea(1)s of (economic) development and commodification of nature as a means to achieve that development. ${ }^{20}$ One final issue, evident in treaties and international law more generally, is that international law is directed mainly to States as the primary actors in international law and this, in combination with the primacy of sovereignty, prevents it from really addressing the problematic behaviours and actions ascribed to certain non-State actors, particularly

\footnotetext{
${ }^{13}$ Convention for the Protection of the Marine Environment of the North-East Atlantic (adopted 22 September 1992, entered into force 25 March 1998) 19922354 UNTS 67. See, also Paloniitty, Nzegwu and French, chapter 14 in this volume.

${ }^{14}$ United Nations Framework Convention on Climate Change (adopted 9 May 1992, entered into force 21 March 1994) 19921771 UNTS 107.

${ }^{15}$ Convention on the Protection of the Marine Environment of the Baltic Sea 1992 (adopted 9 April 1992 , entered into force 17 January 2000) 2009 UNTS 195. See, also Diz, chapter 20 in this volume.

${ }^{16}$ United Nations Convention to Combat Desertification in those Countries Experiencing Serious Drought and/or Desertification, Particularly in Africa 1994 (adopted 14 October 1994, entered into force 26 December 1996) 1954 UNTS 3. See, Morrow, chapter 19 in this volume.

${ }^{17}$ See for example, the Non-Legally Binding Authoritative Statement of Principles for a Global Consensus on the Management, Conservation and Sustainable Development of all Types of Forests (13 June 1992) UN Doc A/CONF.151/6/Rev.1.

${ }^{18}$ See, Nijman and Aust, chapter 6 in this volume.

19 Trail Smelter Arbitration (Canada v. United States) (1938, 1941) 3 RIAA 1905

${ }^{20}$ See Sam Adelman, 'Rio+20: sustainable injustice in a time of crises' (2013) 4(1) JHRE, 6; Sam Adelman, 'Between the Scylla of Sovereignty and the Charybdis of Human Rights: The Pitfalls of Development in Pursuit of Justice' (2008) 2 Hum Rts \& Int'l Legal Discourse 17; and Adelman, chapter 4 in this volume.
} 
This is a draft chapter/article. The final version will be available in Planetary Boundaries and International Law edited by Duncan French and Louis Kotzé forthcoming 2020/21, Edward Elgar Publishing Ltd.

The material cannot be used for any other purpose without further permission of the publisher, and is for private use only.

multi-national companies (MNCs), despite the fact that these companies benefit from the ideological and practical advantages related to their corporate juridical subjectivity. ${ }^{21}$

\section{Monitoring, enforcement and the nature of treaty obligations}

While some of the treaties contain monitoring provisions, with States required to report on the actions they have taken, enforcement action against States that fail to meet agreed targets are often weak or non-existent. ${ }^{22}$ To those new to international law, this construction of a legal system appears odd. Those subject to the law both make it and enforce it, and in practice there is little enforcement action unless one State believes that it has been, or will be harmed by the actions of another, or by their failure to act. For example, Ireland pursued the United Kingdom (UK) over potential radioactive pollution release from the MOX plant because it foresaw a direct threat to its fisheries activities in the Irish Sea, and, consequently, to its economy, ${ }^{23}$ but without such direct links any attempts at enforcement of obligations by individual States is unlikely. Thus, for example, the UNFCCC and related agreements provide for reporting by parties of compliance with their targets to reduce greenhouse gas emissions, but there is no real enforcement action where States fail to meet their targets. Under the Paris Agreement, for example, the model adopted focuses on facilitation and support, rather than the adoption of punitive measures. ${ }^{24}$

Distinctions in existing enforcement mechanisms partly rest upon the ease or difficulty of demonstrating causation. Whereas it is challenging in the extreme to demonstrate that a particular harm, such as the loss of crops caused by increased drought, is directly linked to greenhouse gas emissions from any given State, it is relatively straightforward to demonstrate that radioactive pollution has emanated from a particular State. In part the general lack of enforcement, particularly in relation to global problems such as climate change, can be traced to the primacy of the concept of sovereignty within the Westphalian system of international

\footnotetext{
${ }^{21}$ Anna Grear Redirecting Human Rights: Facing the challenge of corporate legal humanity (Palgrave Macmillan, 2010); Anna M Grear, 'Towards a New Horizon: in Search of a Renewing Socio-Juridical Imaginary' (2013) 3(5) Oñati Socio-Legal Series, 980. See, also Kim and Kotzé, chapter 3 in this volume. ${ }^{22} \mathrm{See}$, for a detailed discussion, Ebbesson, chapter 10 in this volume.

${ }^{23}$ The MOX Plant Case (Ireland v. United Kingdom) Provisional Measures, Order of $3^{\text {rd }}$ December 2001 ITLOS 1095 The provisional measure order required the UK and Ireland to "exchange further information with regard to possible consequences for the Irish Sea arising out of the commissioning of the MOX plant, monitor risks or the effects of the MOX plant for the Irish Sea and devise, as appropriate, measures to prevent pollution of the marine environment which might result from the operation of the MOX plant".

${ }^{24}$ On compliance and enforcement models see, Jutta Brunnée, "Multilateral Environmental Agreements and the Compliance Continuum" in Gerd Winter (ed) Transnational Governance of Environmental Change, (Cambridge University Press, 2005).
} 
This is a draft chapter/article. The final version will be available in Planetary Boundaries and International Law edited by Duncan French and Louis Kotzé forthcoming 2020/21, Edward Elgar Publishing Ltd.

The material cannot be used for any other purpose without further permission of the publisher, and is for private use only.

law, which is designed to prevent the universal hegemony of any given State or ruling party, ${ }^{25}$ and to protect States from external interference. ${ }^{26}$

From the clear enunciation of the rule that sovereignty over a territory prevents interference by other States in the Island of Palmas Case, ${ }^{27}$ to its repetition in the United Nations (UN) Charter, ${ }^{28}$ sovereignty underpins our modern international legal system. The principle of non-interference which is integral to it, serves as a limit to the possibility of interference in activities that are seen as internal to States. This presents a challenge in terms of preventing breaches of the planetary boundaries as enforcement of obligations rests upon an identifiable harm traceable to an identifiable cause within a State or States' territory/ies. The problem here is that the nature of the planetary boundaries is such that the chain of causation is not always easily established. ${ }^{29}$ For example, ocean acidification is caused by increased absorption of carbon dioxide and, as with climate change, it is not easy to link the specific increases in acidification to any one State's emissions. Similarly, aerosol loading is affected by myriad emissions of different types from different States. While some such as chlorofluorocarbons (CFCs) may be traceable, ${ }^{30}$ others may not be so easily traced to their source. In addition, some of the planetary boundaries may be breached without harm actually occurring, for the purpose of international environmental law. For example, the biosphere may be severely harmed through degradation of ecosystems which lie wholly within the jurisdiction of individual States. Removal of forest cover is not ostensibly an issue in international law if the forest is found wholly within the jurisdiction of a single State, as there is no obvious harm to another State, so too eradication of non-migratory species within a single State (such as beavers in the UK). Nonetheless, these actions may in combination lead to a breach of the biosphere's integrity, or undermine measures to mitigate climate change, or harm to the other planetary boundaries. The management of wetlands, for example, can play a key role in the treatment of landfill leachate, ${ }^{31}$ and in managing nitrogen flows, ${ }^{32}$ but it will most often be undertaken by a single State without any (legal) need to address a potential

\footnotetext{
${ }^{25}$ Hedley Bull, The Anarchical Society: a Study of Order in World Politics (London: Macmillan, 1977).

${ }^{26}$ But see Andreas Osiander, 'Sovereignty, International Relations, and the Westphalian Myth' (2001) 55 (2) International Organization 251 where Osiander argues that the Peace of Westphalia was not designed to codify the concepts of sovereignty and non-interference in the affairs of other States.

${ }^{27}$ Island of Palmas (Netherlands v. United States) 2 RIAA 829.

${ }^{28}$ Charter of the United Nations 1945 (adopted 26 June 1945, entered into force 24 October 1945), Article 2(7) provides "Nothing contained in the present Charter shall authorize the United Nations to intervene in matters which are essentially within the domestic jurisdiction of any state or shall require the Members to submit such matters to settlement under the present Charter...").

${ }^{29}$ See, for example, the discussion in Bleby, Holley and Milligan, chapter 2 in this volume on the difficulty/inappropriateness of downscaling the planetary boundaries.

${ }^{30} \mathrm{M}$ Rigby, S Park, T Saito et al. 'Increase in CFC-11 emissions from eastern China based on atmospheric observations' (2019) 569 Nature 546.

${ }^{31}$ Margit Kõiv, Christina Vohla, Riho Mõtlep et al 'The performance of peat-filled subsurface flow filters treating landfill leachate and municipal wastewater' (2009) 35 (2) Ecol Eng 204.

32 Sheng Zhou, Yutaka Nakashimada, Masaaki Hosomi 'Nitrogen transformations in vertical flow systems with and without rice (Oryza sativa) studied with a high-resolution soil-water profiler', (2009) 35 (2) Ecol Eng 213.
} 
This is a draft chapter/article. The final version will be available in Planetary Boundaries and International Law edited by Duncan French and Louis Kotzé forthcoming 2020/21, Edward Elgar Publishing Ltd.

The material cannot be used for any other purpose without further permission of the publisher, and is for private use only.

harm to other States, as there is no perceived potential transboundary harm. While States may be subject to obligations under global or regional treaties relevant to their management, such as the Ramsar Convention, ${ }^{33}$ or provisions such as Article 3 of the OSPAR Convention, they have considerable discretion as to how to meet these obligations. In addition, breaches can be problematic to police as the inviolability of sovereignty prevents independent inspections being carried out.

Enforcement problems also arise where a harm occurs to or in an area beyond national jurisdiction, for example, the over fishing of fish stocks in the high seas, or degradation of the high sea's ecosystem from pollution. If no State can show its interests have been harmed by such acts, then the chances of any form of enforcement being taken is slim.

\section{The Nature of Obligations}

The concept of sovereignty also lies at the root of the second issue with international treaty obligations relevant to preventing breaches of the planetary boundaries. While it would be ideal to take precautionary action to protect the world from reaching or breaching the planetary boundaries, ${ }^{34}$ there is some debate over the extent to which such an approach is required. ${ }^{35}$ Moreover such action is not easily taken in international law. In treaty practice, for example, the "precautionary approach" has tended only to be embraced in relation to highly risky activities such as dumping at sea. ${ }^{36} \mathrm{In}$ such cases, while the language used in treaty texts may point to the use of a precautionary approach, the degree of risk attached to the activity is so high that the measures may more accurately be characterised as preventive in nature. Equally, preventive action is only taken where there is both strong scientific agreement as to the impacts of a particular activity, or product (such as depletion of the ozone layer by CFCs, mercury poisoning and pollution from persistent organic pollutants), and broad political will amongst States to act. For example, plastics were until relatively recently not perceived of as a problematic material. It has only been as plastic accumulation in the oceans and on land has increased (oceans plastics have increased from around 5 million tonnes in the 1950 s to over 300 million tonnes today), ${ }^{37}$ that plastics have been recognised as problematic materials requiring a legal response. Now States are beginning to adopt measures to tackle plastics pollution, but the political will is not yet present to adopt a treaty that severely restricts plastics pollution, and there is no strong consensus as to the measures to

\footnotetext{
${ }^{33}$ Convention on Wetlands of International Importance Especially as Waterfowl Habitat 1971 adopted 2 February 1971, entered into force 21 December 1975) 995 UNTS 245 entered into force 21 December 1975.

${ }^{34}$ On the concept of precaution in law see for example, Arie Trouwbost (2007) "The Precautionary Principle in General International Law: Combating the Babylonian Confusion” 16 RECIEL 185; Arie Trouwborst Precautionary Rights and Duties of States (Martinus Nijhoff Publishers, 2006).

${ }^{35}$ See Bleby, Holley and Milligan, chapter 2 in this volume.

${ }^{36}$ See, for example the Protocol to the Convention on the Prevention of Marine Pollution by Dumping of Wates and Other Matter, London, (adopted 7 November 1996, entered into force 24 March 2006) 36 ILM 1.

${ }^{37}$ Richard C Thomson, 'Future of the Sea: Plastic Pollution' (Foresight, Government Office for Science, 2017 ) 5.
} 
This is a draft chapter/article. The final version will be available in Planetary Boundaries and International Law edited by Duncan French and Louis Kotzé forthcoming 2020/21, Edward Elgar Publishing Ltd.

The material cannot be used for any other purpose without further permission of the publisher, and is for private use only.

adopt globally to tackle this problem. ${ }^{38}$ Similarly, while the scientific consensus on the causes of the climate emergency are clear, political will and agreement on how to address it is limited. But lack of political will is not confined to highly complex problems such as climate change and plastics pollution; it is also evident in much more straight forward problems such as over fishing. The high financial rewards from over fishing, combined with the fact that ever-declining fish stocks remain a concern, means that even where scientific evidence points to the need to reduce or even ban fishing of certain stocks, it can prove extremely difficult to adopt measures to effectively manage the fish stocks. ${ }^{39}$

The primacy of the notion of sovereignty in the international system when combined with the primacy of the liberal market economy and conceptions of "development" within the global community, make generating the political will to act to address potential and even recognised threats problematic. ${ }^{40}$ In this context, the determinative and structural role of State consent in international law-making further challenges the achievement of an effective international regime. ${ }^{41}$ It might either prevent any agreement being reached, or weaken the content of an agreement where attempts to achieve a common agreement or to reconcile different views lead to the adoption of weak or ambiguous provisions. And even when an agreement is reached, it might not enter into force for several years, especially when controversial or ambiguous measures cause States to withhold ratification of the treaty. ${ }^{42}$ Sovereignty, and its expression in the form of consent, also limits the ability of individual States to take action, for example, in the form of trade sanctions, to persuade/force others to adopt particular behaviours.

\section{The idea(1) of development}

Perhaps the key stumbling block to adopting effective measures for global environmental protection and for preventing breaches of the planetary boundaries, is that any negotiation or implementation of international agreements takes place in the context of a system which continues to posit the idea(l) of development as the norm to aspire to. Thus

"[d]eveloping countries rightly yearn to catch up with the living standards enjoyed in developed countries. ... If the Earth's natural resource base were infinite, catching up by developing countries, continued growth in high-income countries, and further global

\footnotetext{
${ }^{38}$ See, for example Kirk and Popattanachai (n 2); Ina Tessnow-von Wysocki and Philippe Le Billion 'Plastics at Sea: Treaty Design for a Global Solution to Marine Plastic Pollution' (2019) 100 Env Sc and Pol 94.

${ }^{39}$ Seth Korman, 'International Management of a High Sea Fishery: Political and Property-Rights Solutions and the Atlantic Bluefin' (2011) 51 Va J Int'l L 697

${ }^{40}$ See, Adelman, chapter 4 in this volume.

${ }^{41}$ Similarly, issues of consent can stand in the way of effective enforcement or dispute settlement, Duncan French The Achievements of International Law: Essays in Honour of Robin Churchill, J Hartmann and U Khaliq (eds) (Hart Publishing, 2020).

42 Geoffrey Palmer, 'New ways to make international environmental law' (1992) 86 AJIL 259.
} 
This is a draft chapter/article. The final version will be available in Planetary Boundaries and International Law edited by Duncan French and Louis Kotzé forthcoming 2020/21, Edward Elgar Publishing Ltd.

The material cannot be used for any other purpose without further permission of the publisher, and is for private use only.

population growth, would all be relatively straightforward. To catch up with the rich countries, the developing countries would invest in technology, infrastructure, and human capital (especially health and education), and step by step, would narrow the income gap with today's high-income countries. ...That, after all, is the current trajectory of Brazil, China, and India. It is also the preceding path of Japan and Korea. It is the hoped-for path of Africa as well." 43

In this system, the developed world continues to be presented as the future of the developing world, and the present of the developing world, as the past of the developed world. ${ }^{44}$ Thus, although alternative visions exist in theory at least, ${ }^{45}$ the generally accepted view is that some countries have attained a state of 'development' towards which the others are striving, and which can only be reached through the increasing commodification of nature. In this conception of development, the focus is on the efficient appropriation of nature and the dream of material comfort.

This view of development which reduces nature to "a mere appendage", ${ }^{46}$ to be managed through law, science and technology, ${ }^{47}$ has been evident in international law since the first major UN conference on natural resources, the 1949 UN Scientific Conference on Conservation and Utilization of Natural Resources. States that took part in the conference discussed how economic utilization could be combined with ecologically sound management of natural resources. This view of environment as an appendage to be managed is still obvious in provisions relating to the management of shared resources such as fish stocks ${ }^{48}$ and shared watercourses, ${ }^{49}$ where provision is made for economic interests to be considered in setting optimum or equitable utilization alongside, or in priority to, environmental issues. ${ }^{50}$ More than this, however, this view of the environment as something for humans to use or manage as they wish underpins the approach in international law in general to environmental issues. Thus, treaties focused on conservation of biodiversity still recognise the use of resources as a

\footnotetext{
${ }^{43}$ Johan Rockström, Jeffrey D Sachs, Marcus Öhman and Guido Schmidt-Traub, 'Sustainable Development and Planetary Boundaries' (2013) Background research paper for the UN High-Level Panel of Eminent Persons on the Post-2015 Development Agenda $2<$ https:/www.eesc.europa.eu/resources/docs/sustainable-developmentand-planetary-boundaries.pdf $>$ accessed 01 April 2020.

${ }^{44}$ Sundhya Pahuja, 'Changing the World: The Ethical Impulse and International Law' in Raimond Gaita and Gerry Simpson (Eds.), Who's Afraid of International Law? (Monash University Press 2017).

${ }^{45}$ See, for example, Eduardo Gudynas "Value, Growth, Development: South American Lessons for a New Ecopolitics" (2019) 30 (2) Cap, Nat, Soc, 234-243, see also Sam Adelman, 'Planetary Boundaries, Planetary Ethics and Climate Justice in the Anthropocene' chapter XX this volume.

${ }^{46}$ Arturo Escobar, Encountering development: The making and unmaking of the Third World (Princeton University Press 1995) 37.

${ }^{47}$ Björn-Ola Linnér, 'The Cocoyoc Declaration: How It All Began: Global Efforts on Sustainable Development from Stockholm to Rio'. (6th Nordic Conference on Environmental Social Sciences, 2003)

${ }^{48}$ United Nations Convention on the Law of the Sea (adopted 10 December 1982, entered into force 16 November 1994) 1833 UNTS 3 (UNCLOS) part V.

${ }^{49}$ Convention on the Law of the Non-Navigational Uses of International Watercourses 1997 (adopted 21 May 1997, entered into force 17 August 2004) 2999 U.N.T.S. Document I-52106 (Watercourses Convention).

${ }^{50}$ See the Watercourses Convention articles 5 and 6 and UNCLOS Article 61.
} 
This is a draft chapter/article. The final version will be available in Planetary Boundaries and International Law edited by Duncan French and Louis Kotzé forthcoming 2020/21, Edward Elgar Publishing Ltd.

The material cannot be used for any other purpose without further permission of the publisher, and is for private use only.

legitimate and allowable activity. Treaties addressing pollution depart from, and fully embrace, the assumption that pollution is an inevitable by-product of resource use. States are most usually merely enjoined to prevent, reduce or control pollution, with the emphasis generally on the reduction or control of pollution in all but the most hazardous of cases. As Porto-Goncalves and Leff note, the environment "has been captured by the logics of the market and its financial strategies, as well as by normal science, ignoring the power relations that cut across the geopolitics of biodiversity and sustainable development that extends, intensifies and complexifies previous processes of destructive appropriation of natural resources". ${ }^{51}$ In terms of such a framing, our understanding of nature has been relegated to its being an asset, its value equated to its usefulness to human beings. Such a notion of human development at the expense of nature has now become central to environmental debates, ${ }^{52}$ including those concerning planetary boundaries. It also underpins in part at least, the hostility of some states in the global south to the imposition of limits to growth inherent in concepts such as the planetary boundaries. $^{53}$

These views of development and of the environment disregard different forms of relating to nature; forms that require not only the technical thematization of nature, but also the ability to experience it. In particular, the views of those who are "beyond development", i.e., those who are usually viewed as underdeveloped, tend to be disregarded. As explained by Mignolo, to be considered "'underdeveloped' in a highly industrialized world also implies being 'behind' in spirit and knowledge". ${ }^{4}$

While there are some attempts now to draw in other understandings and other voices to the development or implementation of international law, for example, through measures for public participation in international decision-making, these measures tend to be rather limited. They are largely functional in nature, designed to draw in additional information to be used in decision making that fits within these conceptions of development and of the environment, rather than to challenge existing conceptions. ${ }^{55}$ As Zhouri, for example, notes in relation to environmental impact assessment procedures,

\footnotetext{
51 Carlos Walter Porto-Gonçalves and Enrique Leff, 'Political Ecology in Latin America: The Social ReAppropriation of Nature, The Re-Invention of Territories and the Construction of an Environmental Rationality' (2015) 35 Desenvolvimento e Meio Ambiente 65, 70.

${ }^{52}$ It is interesting to note that continued development, even at the cost of some environmental degradation, was believed not only to be good for the environment in the long run, but also as "the only answer to many of the environmental problems" of developing countries. Ibid.

${ }^{53}$ See, Kim and Kotzé, chapter 3 in this volume.

${ }^{54}$ Walter Mignolo, 'Delinking: The rhetoric of modernity, the logic of coloniality and the grammar of decoloniality' (2007) 21 Cultural Studies, 449, 473

${ }^{55}$ Elizabeth A. Kirk, 'The Role of Non-State Actors in Treaty Regimes for the Protection of Marine Biodiversity' in M. Bowman and E. Goodwin (eds.), Research Handbook on Biodiversity and Law (Edward Elgar 2016) 95; Pia Marchegiani, Elisa Morgera and Louisa Parks 'Indigenous peoples' rights to natural resources in Argentina: the challenges of impact assessment, consent and fair and equitable benefit-sharing in cases of lithium mining' (2020) 24 TIJHR 224.
} 
This is a draft chapter/article. The final version will be available in Planetary Boundaries and International Law edited by Duncan French and Louis Kotzé forthcoming 2020/21, Edward Elgar Publishing Ltd.

The material cannot be used for any other purpose without further permission of the publisher, and is for private use only.

The language of impact, hegemonic within the sustainable environment discourse, presupposes the environment as an objective reality independent and separated from society. As an object, the environment is to be analyzed in the light of scientific knowledge and technical assessment. As a consequence, other epistemologies and knowledges are disregarded as legitimate environmental perceptions and discourses within the environmental field, a fact that contributes to the increase of inequalities and the perpetuation of the coloniality of knowledge and power. ${ }^{56}$

Thus, procedural arrangements such as environment impact assessments that enable public participation, simply become costly legitimation tools for the dominant world view. They do not provide an institutional space in which the meaning of development, sustainability, boundaries and a safe operating space can be contested. Nor do they provide an opportunity to really learn the true extent and scope of potential environmental and human impacts associated with development. The experience of the Krenak indigenous communities affected by the Samarco dam disaster in Brazil illustrates this issue rather clearly. As the 13-year-old Krenak activist Kathy Krenak explained: “The name 'Krenak' means 'People of the River'. Basically, it's our life. [The flood] ends up killing the Krenak people." 57

Even where this reductive relationship with nature is challenged on the international stage, those challenges often fail to change the path of commodification. For example, the indigenous peoples represented in the First International Forum of Indigenous Peoples on Climate Change, held in Lyon, France in September 2000, rejected the inclusion of carbon sinks under the Clean Development Mechanism (CDM) because:

...it reduces our sacred land and territories to mere carbon sequestration which is contrary to our worldviews and philosophy of life. Sinks in the CDM would constitute a worldwide strategy for expropriating our lands and territories and violating our fundamental rights that would culminate in a new form of colonialism. Sinks in the CDM would not help to reduce GHG emissions; rather it would provide industrialized countries with a ploy to avoid reducing their emissions at source [...] the CDM pose the threat of invasion and loss of our land and territories by establishing new regimes for protected areas and privatization. We emphatically oppose the inclusion of sinks, plantations, nuclear power, mega-hydroelectric and coal. Furthermore, we oppose the development of a carbon market that would broaden the scope of globalization. ${ }^{58}$

\footnotetext{
${ }^{56}$ Andreá Zhouri Working Paper 75 "Mapping Environmental Inequalities in Brazil"' (2014) desiguALdades.net International Research Network on Interdependent Inequalities in Latin America < https://www.desigualdades.net/Working_Papers/Search-Working-Papers/working-paper-75-_mappingenvironmental-inequalities-in-brazil_index.html> accessed on 02 April 2020.

57 Jonathan G Wald, 'Feral Disasters, Feral Recovery: Ecosystem - Based Disaster Risk Reduction and the Governance of Nature'. (Feral: A nearly carbon - neutral conference, 2018) 1.

58 Porto-Gonçalves and Leff (n 51) 70.
} 
This is a draft chapter/article. The final version will be available in Planetary Boundaries and International Law edited by Duncan French and Louis Kotzé forthcoming 2020/21, Edward Elgar Publishing Ltd.

The material cannot be used for any other purpose without further permission of the publisher, and is for private use only.

Nevertheless, a carbon market has been created and the use of technical and market-oriented solutions not only for (under)development, but also for environmental problems, has been reinforced. As such, the international debate, including our responsibility towards the environment, is monetized. Thus the climate change regime, "does not seek to fundamentally change consumption and/or carbon-intensive lifestyles, rather allowing for a continuation of existing practices until ecological thresholds are reached". ${ }^{59}$ The consequence is that the development of a "throw-away society" was and remains inevitable. Valuable resources such as rare earth minerals, phosphorous, ${ }^{60}$ and even the (apparently plentiful) hydrocarbons used in the production of plastics and in transport and heating are simply used and discarded as waste.

Such a monetized and development-focused vision of environmental protection also leads to tensions between developed and developing States that play out in the negotiation and creation of treaty regimes. In some contexts, this tension manifests in the actions taken by those States which already have access to a particular market or resource (such as States which fish a particular fish stock) to exclude other States from the market and from the opportunity to use the resource. Such practices can also occur when creating new treaty regimes such as in the development of regimes to address tuna fishing. ${ }^{61}$

In other contexts, the tension is played out through negotiations on questions of access and benefit sharing. We see this in numerous regimes, ranging from the CBD, to management and use of the deep seabed under the UN Convention on the Law of the Sea, ${ }^{62}$ to the control of global diseases. ${ }^{63}$ These debates centre on questions of equity with regard to who has the capacity to access resources and who gains benefits from their exploitation. The key issue for our present purposes is that these debates largely centre on use and commodification of nature, ${ }^{64}$ even where they arise in the context of regimes, such as the $\mathrm{CBD}$, which have apparently been designed with conservation as their main aim. As a result, the dominant liberal market discourse remains largely unchallenged.

\footnotetext{
${ }^{59}$ Rowena Maguire, 'Gender, climate change and the United Nations Framework Convention on Climate Change' in Susan H. Rimmer and Kate Ogg (eds.), Research Handbook on Feminist Engagement with International Law (Cheltenham: Edward Elgar, 2019) 76.

${ }^{60}$ Martin Blackwell, Tegan Darch, Richard Haslam 'Phosphorus use efficiency and fertilizers: future opportunities for improvements' (2019) 6(4) Front Ag Sci and Eng 332.

${ }^{61}$ Organisation for Economic Cooperation and Development (OECD) Strengthening Regional Fisheries Management Organisations (OECD Publishing 2009) 53.

62 See generally Elisa Morgera 'The need for an international legal concept of fair and equitable benefitsharing' (2016) 27 EJIL 353

${ }^{63}$ Stephanie Switzer, Elisa Morgera, Elsa Tsioumani and Gian Luca Burci, 'Biodiversity, pathogen sharing and international law' in Stephania Negri (Ed.), Environmental Health in International and EU Law: Current Challenges and Legal Responses (Routledge, 2019) 253.

${ }^{64}$ But see Elisa Morgera, 'Under the radar: the role of fair and equitable benefit-sharing in protecting and realising human rights connected to natural resources' (2019) 23 (7) IJHR 1098.
} 
This is a draft chapter/article. The final version will be available in Planetary

Boundaries and International Law edited by Duncan French and Louis Kotzé forthcoming 2020/21, Edward Elgar Publishing Ltd.

The material cannot be used for any other purpose without further permission of the publisher, and is for private use only.

\section{States as primary actors}

The final factor we consider is the focus of international law, which primarily remains directed at States. While non-State actors have (increasing) rights to participate in international law whether in the policy making process, ${ }^{65}$ or in enforcement of their own rights, ${ }^{66}$ holding nonState actors, and in particular corporate actors, to account for environmental harms in international law is problematic. Many of the activities that threaten the planetary boundaries are undertaken by corporations, often multi-national corporations; the rights and duties of which are primarily governed by the laws of the States in which they are registered or operate. ${ }^{67}$ Holding such actors to account is problematic particularly where low value subsidiary companies are established to undertake risky activities, such as extraction of oil and gas. Problems are most obvious where large multi-national companies extract minerals, oil or gas in countries in the global south, particularly where these countries have rather weak environmental regulations in order to stimulate economic growth and investment. Here the disparities in the financial, technical and human resources between corporations and States can be significant. The MNCs, which may have resources many times the size of the resources of the State in question, will often be able to negotiate agreements in their favour, ${ }^{68}$ or simply to walk away when damage, liability and costs arise. The assignment of responsibility to MNCs also presents legal challenges as the host state might fail to exercise its regulatory obligations. ${ }^{69}$ Even though company law and tort law can be used to hold a parent company liable, they set demanding thresholds which make holding companies to account difficult. ${ }^{70}$ In addition, most domestic systems seem to require a territorial nexus for the exercise of jurisdiction, imposing further challenges to the judicial determination of parent companies liability for the harm caused by their subsidiary(ies). ${ }^{71}$ Without an international court with jurisdiction over

\footnotetext{
${ }^{65}$ See, for example, Steve Charnovitz, 'Two Centuries of Participation: NGOs and International Governance' (1996-1997) 18 Mich JIL 183.

${ }^{66}$ As well as rights under various human rights treaties to bring legal actions in court or raise complaints at compliance commissions against States, individuals have rights of petition to the compliance commission under the 1998 Convention on Access to Information, Public Participation in Decision-making and Access to Justice in Environmental Matters (Aarhus Convention) (adopted 25 June 1998, entered into force 30 October 2001) 2161 UNTS 447. These latter rights are interesting in that they focus on access to information etc. in relation to the environment rather than the direct protection of individual human rights seen within human rights treaties.

${ }^{67}$ Barcelona Traction, Light and Power Company Limited (Belgium v. Spain) I.C.J. Reports [1970] 3. See also Kim and Kotzé, chapter 3 in this volume.

${ }^{68}$ See, for example, Thomas W. Wälde, 'Renegotiating acquired rights in the oil and gas industries: Industry and political cycles meet the rule of law' (2009) 1 JWELB 55

${ }^{69}$ As happened, for example, when Transfigura dumped toxic waste in Cote d'Ivoir. Côte d'Ivoir, chose to give the company immunity from prosecution. See Amnesty International and Greenpeace Netherlands The Toxic Truth: About a company called Trafigura, a ship called the Probo Koala, and the dumping of toxic waste in Côte d'Ivoire (Amnesty International/Greenpeace Netherlands, 2012).

${ }^{70}$ Radu Mares, 'Liability within corporate groups: Parent company's accountability for subsidiary human rights abuses' in Surya Deba and David Birchall (Eds), Research Handbook on Human Rights and Businesses (Cheltenham: Edward Elgar, 2020).

${ }^{71}$ Chilenye Nwapi, 'Jurisdiction by Necessity and the Regulation of Transnational Corporations' (2014) 30(78) Utrecht JIEL 24
} 
This is a draft chapter/article. The final version will be available in Planetary Boundaries and International Law edited by Duncan French and Louis Kotzé forthcoming 2020/21, Edward Elgar Publishing Ltd.

The material cannot be used for any other purpose without further permission of the publisher, and is for private use only.

corporate abuses, international law also fails to offer a relevant framework to deal with the accountability of MNCs. . ${ }^{72}$

While cases such as the Vedanta case $^{73}$ suggest that instances of parent companies avoiding liability may be reducing, at present, most corporate actors still do not incur sufficient liability for their socio-ecological destructive activities. At the same time, other types of non-State actors such as those operating in organised crime, exploit gaps in enforcement by States to illegally trade species, or to sell illegally captured animal products across borders. ${ }^{74}$ The international legal system based on the primacy of State sovereignty prevents us from comprehensively and effectively tackling deeply persistent problems such as these.

\section{Preventing or Adapting to Breaches of the Planetary Boundaries}

There are two directions in which international law-making could travel to address the multiple and varied concerns discussed above. The first would be to undertake a fundamental review of existing legal provisions and their relationship to commodification, including a review of the ethics underpinning these laws. This might see land rights, fishing rights, drilling rights, shareholder rights, intellectual property rights and State sovereignty, for example, all being reconsidered in a critical way. A second option could be to focus on how we respond to the socio-ecological constraints placed upon our society in light of the fact that we have already crossed several planetary boundaries and threaten to cross others. On balance, it seems as if the international community has chosen to focus most of its attention on the second option. For example, climate change is increasingly considered through the lens of adaptation, be that how to manage retreating coastlines as a result of sea-level rise, ${ }^{75}$ or how to manage extreme weather events such as flooding, ${ }^{76}$ or how to address the

\footnotetext{
72 Olivier de Schutter, 'Regulating Transnational Corporations: A Duty under International Human Rights Law' (2014) Contribution of the Special Rapporteur on the right to food, Mr. Olivier De Schutter, to the workshop "Human Rights and Transnational Corporations: Paving the way for a legally binding instrument" convened by Ecuador, 11-12 March 2014, during the 25th session of the Human Rights Council.

$<$ https://www.ohchr.org/Documents/Issues/Food/EcuadorMtgBusinessAndHR.pdf> accessed 02 April 2020.

${ }^{73}$ Vedanta Resources PLC and another (Appellants) v Lungowe and others (Respondents) [2019] UKSC 20. In this case, the UK Supreme Court decided that the claim brought by 1826 Zambian villagers in 2015 against the UK based Vedanta and its subsidiary KCM could proceed to trial on the substantive issues in English courts. The claimants alleged that they had suffered personal injury, damage to property and loss of income, amenity and enjoyment of land as a result of the alleged pollution and environmental damage caused by discharges of harmful substances from the Nchanga copper mine into local waterways since 2005.

${ }^{74}$ See, for example, Daan van Uhm and foDina Siegel 'The illegal trade in black caviar' (2016) 19 Trends in Organized Crime 67

${ }^{75}$ Vera Köpsel and Cormac Walsh, 'Coastal landscapes for whom? Adaptation challenges and landscape management in Cornwall' (2018) “ 97 Marine Policy 278

${ }^{76}$ See, for example, Ruth Dittrich, Adam Butler, Tom Ball, Anita Wreford, Dominic Moran, 'Making real options analysis more accessible for climate change adaptation. An application to afforestation as a flood management measure in the Scottish Borders’ (2019) “ 245 J Env Mngt 338; Tahmina Akter, Philippe
} 
This is a draft chapter/article. The final version will be available in Planetary Boundaries and International Law edited by Duncan French and Louis Kotzé forthcoming 2020/21, Edward Elgar Publishing Ltd.

The material cannot be used for any other purpose without further permission of the publisher, and is for private use only.

movements fish-stocks, ${ }^{77}$ or through consideration of the systems needed to manage disease vectors modified by climate change. ${ }^{78}$ In the majority of instances, however, we neither consciously adapt to the fact that we are hurtling towards breaching the planetary boundaries, nor take measures that are adequate to slow or stop our encroachment onto the boundaries. We "adapt" to the growing waste produced by our throw-away society through improved collection and recycling, ${ }^{79}$ and better communication between importers and exporters, ${ }^{80}$ rather than modification of consumption patterns to produce less waste. Energy efficiency measures are encouraged, ${ }^{81}$ while new frontiers are opened up to enable further exploitation of hydrocarbons and minerals in the deep seabed ${ }^{82}$ thus ignoring the fact that in opening these areas to exploitation we risk further reductions in biodiversity, and further pollution by chemicals, thus continuing our journey towards breaches of the planetary boundaries.

We suggest that there is a further problem should we choose to make adaptation the primary norm of law as its role changes in light of breaches or threatened breaches of the planetary boundaries. That problem is that there are some environmental changes (such as the loss of pollinators) which we may never be able to adapt to. We therefore turn to focus our discussion on the first route - addressing the relationship between rights and commodification.

\section{Law, Rights and Commodification}

Law has played two roles in relation to commodification, both granting exclusive access to resources and providing routes to control activities. Although the right to property has "played a crucial role (...) in turning interconnected ecosystems into realms of infinite commodification and exchange, and in extracting and conceptually separating an atomized

\footnotetext{
Quevauviller, Steven J. Eisenreich, and Guido Vaes, Impacts of climate and land use changes on flood risk management for the Schijn River, Belgium' (2018) 89 Env Scie and Pol 163.

${ }^{77}$ Manuel Barange, Tarûb Bahri, Malcolm C.M. Beveridge, Kevern L. Cochrane, Simon Funge-Smith and Florence Poulain (Eds), Impacts of climate change on fisheries and aquaculture: Synthesis of current knowledge, adaptation and mitigation options (FAO Fisheries and Aquaculture Technical Paper 2018) 627.

${ }^{78}$ Victor Galaz, Global Environmental Governance, Technology and Politics: The Anthropocene gap (Edward Elgar, 2014).

${ }^{79}$ See Rafia Afroz, Ataur Rahman, Muhammad Mehedi Masud and Rulia Akhtar, 'The knowledge, awareness, attitude and motivational analysis of plastic waste and household perspective in Malaysia' (2017) 24 Environ Sci Pollut Res 2304; Josh Gabbatiss, 'Plastic-eating enzyme accidentally created by scientists could help solve pollution crisis' (The Independent, 16 April 2018); Melissae Fellett, 'Improving a plastic-degrading enzyme for better PET recycling Adding sugars to a cutinase enzyme makes it more effective at breaking down polyethylene terephthalate' (Chemical and Engineering News, 28 February 2018).

${ }_{80}$ Basel Convention Decision BC-14/13: Further actions to address plastic waste under the Basel Convention

${ }^{81}$ See, for example, The Energy Efficiency (Private Rented Property) (England and Wales) Regulations 2015 UKSI 962; Commission Regulation (EC) 244/2009 of 18 March 2009, OJL 76/3, 24 March 2009.

${ }^{82}$ Marc-Andrej Felix Mallin, 'From sea-level rise to seabed grabbing: The political economy of climate change in Kiribati' (2018) 97 Marine Policy 244
} 
This is a draft chapter/article. The final version will be available in Planetary Boundaries and International Law edited by Duncan French and Louis Kotzé forthcoming 2020/21, Edward Elgar Publishing Ltd.

The material cannot be used for any other purpose without further permission of the publisher, and is for private use only.

human individual from the intertwined mesh of life"; 83 at the same time it is one of the oldest means of legally protecting the environment with landowners, or right holders able to protect the land etc. within their control from further degradation. ${ }^{84}$ At the same time, property rights enable a clear link between certain forms of pollution and a responsible individual. The "landowner", for example, retains responsibility for ensuring that nothing is introduced to their land or takes place on it which will harm their neighbours. This has extended both to the international obligation of States not to harm their neighbours and areas beyond their jurisdiction, and to the granting of rights to use particular resources or pollute in particular ways to those with an identifiable interest in an activity or area of land.

Perhaps because of the perceived ability of property owners to protect property and thus the environment, a solution to perceived problems, such as Hardin's tragedy of the commons, ${ }^{85}$ has been to extend the notion of property and grant rights to those agents deemed to have an interest in the area and/or activity. For example, property rights have for some time been used to control access to fisheries and as a response to the threats to vulnerable/indigenous communities from development. ${ }^{86}$ In the latter case the focus has been on the use of rights such as community-based property rights, to protect the interests of indigenous peoples, ${ }^{87}$ as well as prior informed consent and access and benefit sharing. ${ }^{88}$ For example, the interAmerican system of human rights recognizes property rights as a means of protecting indigenous communities' relationship with nature:

Territory is uniquely important for indigenous peoples, as it is a fundamental requirement for the development of their culture, spiritual life, integrity, and economic survival. Those groups consider certain places, phenomena or natural resources to be sacred, in accordance with their cosmovision and traditions. In the inter-American system, the IACHR and the I/A Court H.R.[Inter-American Commission on Human Rights and the Inter-American Court of Human Rights] have held that that indigenous peoples' spiritual relationship with the space that they occupy collectively speaking is protected by Article 21 of the American Convention and Article XXIII of the American Declaration. They have also expressly recognized the right of indigenous and tribal peoples to the natural resources situated in the territories that they have 'traditionally

\footnotetext{
${ }^{83}$ Usha Natarajan and Julia Dehm, 'Where is the Environment? Locating Nature in International Law' (2019) 3 Third World Approaches to International Law Review: Reflections $<$ https://twailr.com/where-is-theenvironment-locating-nature-in-international-law/> accessed 02 April 2020

${ }^{84}$ Dinah Shelton, 'Nature as a legal person' (2015) 22 Vertigo - La revue eletronique en sciences de l'environnment 22.

${ }^{85}$ Garrett Hardin, 'The Tragedy of the Commons' (1968) 162 (3859) Science 1243

${ }^{86}$ Peter H Pearse, 'From Open Access to Private Property: Recent Innovations in Fishing Rights as Instruments of Fisheries Policy' (1992) 23 ODIL 71.

${ }^{87}$ Daniel Barstow Magraw and Lauren Baker, 'Globalization, Communities and Human Rights: CommunityBased Property Rights and Prior Informed Consent' (2007) 35 Denv J Int'l L \& Pol'y 413.

${ }^{88}$ Morgera (n 64); Marchegiani, Morgera and Parks (n 55)
} 
This is a draft chapter/article. The final version will be available in Planetary Boundaries and International Law edited by Duncan French and Louis Kotzé forthcoming 2020/21, Edward Elgar Publishing Ltd.

The material cannot be used for any other purpose without further permission of the publisher, and is for private use only.

used and [that are] necessary for the very survival, development and continuation of such people's way of life'. ${ }^{89}$

In this example the right to property is also combined with rights to cultural identity, nondiscrimination and self-determination. ${ }^{90}$ Even though the close relation indigenous communities have with nature cannot be reduced to a matter of possession and use, when traditional lands are involved, the right to property remains the basic foundation of the InterAmerican Court of Human Rights jurisprudence..$^{91}$

Property rights are, however, inadequate to address transboundary problems, be that transboundary pollution, or the management of transboundary species. They are also problematic as a means to preserving traditional interactions between humans and the environment. For example, if a particular indigenous peoples' subsistence lifestyle is largely dependent on resources distributed across large expanses of territory, ${ }^{92}$ and their seasonal movement patterns are restricted to an area delimitated by legal (property) boundaries, their lifestyle may then become impossible to sustain. Such boundaries may also disrupt the intimate spiritual relationship between the identity and cultural integrity of indigenous peoples and their environment. ${ }^{93}$ Relying on property rights may also undermine traditional, sustainable land management practices by "placing ancestral land rights on the same footing as the private rights acquired by commercial developers". ${ }^{94}$ A further problem is that using (property) rights as a means to protect the environment is dependent upon the benefit or utility attached to that environment. Without a perceived benefit or utility, the likelihood of right holders taking action to protect the environment is significantly reduced. In the context of breaches of the planetary boundaries these limitations are significant. It may appear to benefit a landowner more in the short term to clear a forest for farming, for example, than to maintain the forest to protect the biosphere.

Despite these problems, we have continued to use rights as an innovative way of protecting the environment, but emphasis is now placed on a different form of rights. Rather than property

\footnotetext{
${ }^{89}$ Inter-American Commission of Human Rights Situation of Human Rights of the Indigenous and Tribal Peoples of the Pan-Amazon Region, OAS/Ser.L/V/II. Doc. 176 (29 September 2019) 31.

${ }^{90}$ The link between property and the protection of human rights is not, however, new and can be traced back to the seventeenth century. See Lorenzo Cotula, Land, Property and Sovereignty in International Law' (2017) 25 CJICL 219

${ }^{91}$ Inter-American Commission of Human Rights, Indigenous and Tribal Peoples' rights of their ancestral lands and natural resources, OEA/Ser.L/V/II. Doc. 56/09 (30 December 2009), paras. 56, 58. For an alternative approach, based on the notion of vida digna developed in the jurisprudence of the Inter-American Court of Human Rights, see Tomas M Antkowiak, 'Rights, Resources, and Rhetoric: Indigenous Peoples and the InterAmerican Court' (2013) 35 U Penn J Intl L 113.

${ }^{92}$ Inter-American Commission of Human Rights (n. 89) 39

93 Ibid.

${ }^{94}$ Cotula (n 90) 243
} 
This is a draft chapter/article. The final version will be available in Planetary Boundaries and International Law edited by Duncan French and Louis Kotzé forthcoming 2020/21, Edward Elgar Publishing Ltd.

The material cannot be used for any other purpose without further permission of the publisher, and is for private use only.

rights, we focus on human rights to (a healthy) environment and rights of nature. ${ }^{95}$ The origins of the right to a healthy environment are found in Principle 1 of the 1972 Stockholm Declaration, ${ }^{96}$ and such rights have since been adopted in numerous regional treaties and gained recognition in the national laws and constitutions of more than 100 States across the world. ${ }^{97}$ In many instances, procedural rights have also been added to these substantive rights. The right is perceived to protect

"nature and the environment not only because of its connection with a utility for the human being or for the effects that its degradation could cause on other people's rights, such as health, life or personal integrity, but because of its importance for the other living organisms with whom the planet is shared, also deserving of protection in themselves." 98

More recently some States have started to recognise the legal rights of rivers, ${ }^{99}$ and fauna, ${ }^{100}$ as a way of ensuring the protection of these entities.

These developments in relation to the right to a healthy environment and of the appropriateness of granting rights to nature might suggest a move away from commodification of nature. ${ }^{101}$ The granting of rights to nature, in particular, suggests a move away from a mere satisfaction of the needs and desires of natural persons to a clearer understanding of the intrinsic value of nature, which requires the consolidation and further expansion of human responsibilities towards the preservation of nature's natural cycles. The introduction of rights for nature creates the possibility of the legal acknowledgement of the world as a living being. It opens space for the articulation, in the legal framework, of ways of living that reject the current development model and the continuing commodification of nature as well as the boundaries created between humans and nature. If we are to avert further breaches of the planetary boundaries then the ability to articulate and embrace within law such different conceptions of our relationship with the environment is key. Views, such as the views of the Andean peasant communities which challenge our perceptions of the separateness of humans from the environment and from the consequent damage to that environment which underpins the breaches of the planetary

\footnotetext{
${ }^{95}$ For a discussion on the use of a variety of rights, including the right to a housing, right to food etc. see Cotula ibid.

${ }^{96}$ United Nations Conference on the Human Environment, Declaration of Principles, (16 June 1972) UN Doc. A/CONF.48/14/Rev.1 59

${ }^{97}$ John H. Knox, 'Report of the Special Rapporteur on the issue of human rights obligations relating to the enjoyment of a safe, clean, healthy and sustainable environment' (24 January 2018) UNGA A/73/188

98 Inter-American Court of Human Rights (15 November 2017) Advisory Opinion OC-23 requested by the Republic of Colombia (15 November 2017) 28.

99 Lidia Cano Pecharroman, 'Rights of Nature: Rivers That Can Stand in Court' (2018) 7 Resources 13

100 Oliver A Houck, 'Noah's Second Voyage: The Rights of Nature as Law' (2017) 31 Tulane ELJ 1.

${ }^{101}$ Even though the right to a healthy environment has been broadly interpreted by the Inter-American Court of Human Rights to encompass both non-humans and humans, its overall development has privileged an anthropocentric perspective. See, Louis J Kotzé, 'The Anthropocene, Earth system vulnerability and socioecological injustice in an age of human rights' (2019) 10(1) JHRE 62.
} 
This is a draft chapter/article. The final version will be available in Planetary Boundaries and International Law edited by Duncan French and Louis Kotzé forthcoming 2020/21, Edward Elgar Publishing Ltd.

The material cannot be used for any other purpose without further permission of the publisher, and is for private use only.

boundaries we are beginning to experience, are essential to transforming the role of law. In the view of the Andean peasants,

"This live world continually re-creates itself through mutual caring by all living beings. This caring depends on an intimate and ongoing dialogue between all living beings (including, again, people, nature, and the gods), a sort of affirmation of the essence and will of those involved. This dialogue is maintained through continual interactions that are social and historical.

Each plot, for instance, demands different cultivation routines, different practices of caring.

$[\ldots]$

Practices and events are never repeated out of a pre-established scheme; on the contrary, knowledge is continually re-created as part of a commitment to strengthening and enriching reality, not to transforming it." 102

If we are to modify the relationship between law, rights and commodification, then we need to continue to engage with such alternative frames of consciousness that perceive and sense nature differently and continue to innovate our approaches to rights. The value of such perspectives in this context will depend on the epistemic plurality they enable and the degree to which they offer examples of a shared human faculty towards repairing and caring for (all) life. This epistemic plurality should reveal the need to revise the assumed conceptual posture reflected in the first photograph of Earth from space, in which we are external to Earth, as this position facilitates the dissemination of the mistaken view that "it is we who surround the environment, not the other way around". ${ }^{103}$ There are, however, a number of challenges to embracing other voices in our development of law.

\section{The Challenges of Embracing Other Voices}

A first challenge in ensuring different viewpoints are reflected in law is to find appropriate frames of understanding. The view of the Andean peasant communities given above is one among several others, which does not assume that economic development is a goal to pursue or that there is a stage of 'underdevelopment' to be overcome. A second challenge is to incorporate those understandings into law, and, as discussed above, our legal procedures do not yet appear able to ensure the incorporation of this broader range of understandings into our legal systems, at least not at the speed required to ensure that the planetary boundaries are not breached. If we are to incorporate such wider world views into law, we must draw more fully

\footnotetext{
102 Escobar supra n.46 at 169.

${ }^{103}$ Vassos Argyrou, The Logic of Environmentalism: Anthropology, Ecology and Postcoloniality (Berghahn Books, 2005) at 95 quoted in Natarajan and Dehm n.83 at 6.
} 
This is a draft chapter/article. The final version will be available in Planetary Boundaries and International Law edited by Duncan French and Louis Kotzé forthcoming 2020/21, Edward Elgar Publishing Ltd.

The material cannot be used for any other purpose without further permission of the publisher, and is for private use only.

on the understandings provided by disciplines other than law, the natural sciences and economics. We know, for example, that culture and popular media can influence the development of law. ${ }^{104}$ The question we have is how to harness culture and popular media to deliver the chances we require to protect the biosphere, or prevent pollution loads exceeding the environment's capacity to absorb it. As Maguire notes, for example, "perspectives from the humanities have a great deal to offer when looking for explanations as to why climate policies might not work in practice, and in exploring the human issues that arise in the implementation of climate policy". ${ }^{105}$ Perhaps they will also provide answers as to how best to induce effective changes in human behaviour. It is not, however, simply a matter of finding wider perspectives. For such understandings to influence the shape of new laws, or the better implementation of existing laws, both policy makers and lawyers need to have the ability to recognise and understand contributions from these different disciplinary perspectives. Doing so, however, requires these groups to expand their methodological toolkit and skills to embrace the findings that other disciplines bring to law-making and the understandings offered by local and indigenous communities. For example, we need tools to enable us to move beyond understanding local accounts of lived experiences as true or false representations of reality, and towards understanding them as instances of discourse and counter-discourse, that involve (local and global) power relations, ${ }^{106}$ which develop understanding of the plurality of views of nature, the environment, development, sustainability and thus might prompt us to think more critically of actions that lead to land system changes, or over consumption of freshwater, or the emission of pollutants.

The third challenge is that to be truly effective in tackling transnational issues, such as prevention of breaches of the planetary boundaries, these wider perspectives must be embraced at the international level. This would require a fundamental reconsideration of the law and its reliance on the fundamental concept of the rights associated with sovereignty. Such a fundamental reconsideration appears unlikely in the near future. Although States have, through the rapid development of international law, agreed to limit rights, such as the freedom of fishing on the high seas, it might, nonetheless be more appropriate to describe the overall focus of international environmental law as ensuring that no harm is caused to the territory or interests of other States as first clearly expressed in the Trail Smelter arbitration. As such, the concept of sovereignty as traditionally understood and the idea(l) of development remain unchallenged.

A final challenge to adopting these new approaches is that the approaches themselves challenge existing rights and, given our aversion to loss, ${ }^{107}$ the existing right holders may contest any

\footnotetext{
${ }^{104}$ Diana Wagner, Competing Cultural Interests in the Whaling Debate: An Exception to the Universality of the Right to Culture (2004-05) 14 Transnat'l L \& Contemp Probs 831 at 853.

${ }^{106}$ Escobar (n 46) 170.

${ }^{107}$ Daniel Kahneman and Amos Tversky, 'Prospect Theory: An analysis of decision under risk' (1979) 47(4) Econometrica 263.
} 
This is a draft chapter/article. The final version will be available in Planetary Boundaries and International Law edited by Duncan French and Louis Kotzé forthcoming 2020/21, Edward Elgar Publishing Ltd.

The material cannot be used for any other purpose without further permission of the publisher, and is for private use only.

changes to their rights which are, or are perceived to be, a diminution of their rights. There are many cases where investors have contested changes to their rights such as the conversion of riparian rights into permits, and "expropriation of land to create national parks". ${ }^{108}$ Similar objections are also raised at the international level. For example, whaling States' responses to the adoption of the moratorium on whaling have clearly indicated their unwillingness to give up particular cultural or economic practices. Such objections are also often raised by companies and other non-State actors through lobbying of individual States or lobbying at intergovernmental meetings. Taking concrete action to avert the catastrophic damage associated with breaches of the planetary boundaries will inevitably mean that rights must be restricted. It can no longer be acceptable to emit chemical pollutants at the scale they are being emitted, or to systematically change land-use, for example, from forest to farmland or from farmland to urban areas. The challenges to these restrictions from current rights holders, be they landowners, States, or the holders of human rights, will make ensuring that we do not cross the planetary boundaries extremely challenging.

\section{Conclusion: A Changing Role for Law?}

Our chapter has so far painted a somewhat gloomy picture of the ability of law, as it is currently framed, to prevent breaches of the planetary boundaries, given the primacy conferred to rights rather than responsibilities within legal systems and within the discipline itself. While various forms of rights have been used, sometimes innovatively, to try to protect the environment, and while they form the foundations upon which limitations of the actions of States and other actors may be built, we have demonstrated that there are problems with relying upon the concept of rights. Rather than playing a leading role in the fight to protect our environment, our laws and the rights they grant privilege the positions of some in respect of resources and entrench the liberal market economic focus on development through the mechanism of rights. When scientists have demonstrated that action is needed, for example, to address nitrogen and phosphorous flows and limit atmospheric aerosol loading, lawmakers have often-times prioritised the interests of rights holders. ${ }^{109}$ What hope then is there that law will have a role to play in the adoption of the precautionary approach necessary to protect our planetary boundaries?

Our suggestion is that if law is to play a role that is something more than a memorial to our folly in relation to the environment, it requires an urgent and critically comprehensive reconsideration, in terms of the content of law, its implementation and enforcement. We have mentioned earlier in this chapter the need to draw upon understandings and worldviews which depart from the "norm" of the liberal market economy and we have pointed to the need

\footnotetext{
108 Cotula (n 90).

${ }^{109}$ Elizabeth A. Kirk, 'Science and the International Regulation of Marine Pollution' in D. Rothwell, K. Scott; T. Stephens; A. Oude Elferink (Eds) Handbook on the Law of the Sea (Oxford University Press 2015) 516
} 
This is a draft chapter/article. The final version will be available in Planetary Boundaries and International Law edited by Duncan French and Louis Kotzé forthcoming 2020/21, Edward Elgar Publishing Ltd.

The material cannot be used for any other purpose without further permission of the publisher, and is for private use only.

to draw more heavily on the understandings some indigenous peoples have of the world. The danger of relying exclusively on this approach is that any new understandings will be received by the legal system and lawyers and interpreted in light of existing legal concepts. In other words, the incorporation of "novel" concepts will be shaped by the autopoietic or selfreferential nature of law, ${ }^{110}$ and the bounded rationality of decision makers will prevent them from moving beyond the current mode of understanding. ${ }^{111}$ The effect will be continued path dependency ${ }^{12}$ in the way we address environmental issues through law-making and implementation. ${ }^{113}$ For example, we may continue to focus on rights as mechanisms to deliver solutions to our environmental problems even when the concept of rights may have nothing within its tool box that can provide a solution to the continuing commodification of nature. Alternatively, our attempts to respond to "new" understandings may lead us to focus on adaptation to the consequences of transgressing the planetary boundaries, rather than prevention of that breach.

A clearer focus is therefore needed in the search for alternative worldviews. We suggest that this focus must provide a counter point to the prevailing notion of rights in law; and so we propose a focus on responsibilities. This would require consideration of, for example, the responsibilities of States and of non-State actors to ensure that ecosystems remain or are restored to good health, responsibilities to ensure that all relevant actors (be they States, multi-national companies, individuals or others) preserve valuable chemicals such as nitrogen and phosphorous in closed systems, and responsibilities for all to adopt energy efficiency actions to minimise emissions of greenhouse gases to name but a few. We also suggest a responsibility to listen to alternative voices which may fall primarily on States, corporations and majority populations.

For this proposal to work we need to be alive to the dangers that even a new focus on responsibility might very well be developed, interpreted and applied in accordance with existing concepts in law which support the commodification of nature. In other words, we need to address the problems of autopoiesis in the legal system, and of path dependency in decision-making, which leads to new approaches being bolted on to existing ones, or interpreted and applied in light of them, and we need to support decision-makers to overcome

\footnotetext{
${ }^{110}$ Niklas Luhman, 'The Unity of the Legal System' in Gunther. Teubner (ed) Autopoietic Law: A New Approach to Law and Society (Walter de Gruyter, 1987) 12; Gunther Teubner, Law as an Autopoietic System translated by Anna Bankowska ((Anne Bankowska and Ruth M. Adler trs, Blackwell, 1993) 111 Max Rheinsten (Ed), Max Weber on Law in Economy and Society (Harvard University Press, 1947); Max Weber, The Theory of Social and Economic Organisation (Collier-Macmillan, 1968). Put simply bounded rationality refers to the fact that all humans are limited in their capacity to know and understand and thus make decisions within the bounds of the knowledge and understanding they possess.

${ }^{112}$ W. Brian Arthur, 'Competing Technologies, Increasing Returns, and Lock-in by Historical Events' (1989) 99 Economic Journal 116; W. Brian Arthur, Increasing Returns and Path Dependency in the Economy (University of Michigan, 1994).

${ }^{113}$ Elizabeth A. Kirk, Alison D. Reeves and Kirsty L. Blackstock, 'Path Dependency and Environmental Regulation' (2007) 25 Env and Planning C: Govt and Pol'y.250
} 
This is a draft chapter/article. The final version will be available in Planetary Boundaries and International Law edited by Duncan French and Louis Kotzé forthcoming 2020/21, Edward Elgar Publishing Ltd.

The material cannot be used for any other purpose without further permission of the publisher, and is for private use only.

their inevitable bounded rationality. These may appear to be insurmountable problems, but we do have existing bodies of understanding to draw upon to help tackle them. The literature on the development and lifecycle of norms reminds us of the role of norm entrepreneurs in the development and dissemination of new norms. ${ }^{114}$ We understand the importance of the norm cascade and norm tipping points in generating compliance and we have some understanding of the ways in which the cascade and tipping point can be generated. Thus we know that the creation or support of epistemic communities, ${ }^{115}$ discourse with those subject to new norms or regulations, ${ }^{116}$ or wider provision of information ${ }^{117}$ through for example the media ${ }^{118}$ can all be crucial in the development of new norms. What we have less understanding of and where we need further research, is in how to bring these mechanisms together in a coherent fashion to ensure that the normative change we seek will be delivered.

The proposal to focus more clearly on responsibilities, of course also leads to a range of questions which, combined, potentially could provide a new research agenda. These questions include: what responsibilities should actors have in respect of the environment? How should such responsibilities be framed to ensure that they do not fall victim to the same problems of path dependency in implementation, and interpretation in light of existing understandings? How should these new responsibilities be communicated to States, companies and the public in a way that ensures they are seen as positive gains rather than potential losses of existing rights? How do we support the generation and adoption of a new norm of responsibility? How do we change legal and popular cultures rapidly in a direction that will enable a sustainable future for human populations? These questions offer some indication of the scale of the task this reconsideration of law might entail. It will not be an easy task to accomplish, but it is one that is urgently needed if we are to avoid crossing more

\footnotetext{
${ }^{114}$ See, for example, Martha Finnemore, and Kathryn Sikkink 'International Norms and Political Change' , (1998) 52(4), International Organization, 887; Christopher D. Hollander and Annie S. Wu, 'The Current State of Normative Agent-Based Systems' (2011) 14 Journal of Artificial Societies and Social Simulation, 6; Moamin A. Mahmoud, Mohd Sharifuddin Ahmad, Mohd Zaliman Mohd Yusoff, and Aida Mustapha 'A Review of Norms and Normative Multiagent Systems' (2014) The Scientific World Journal, (Article ID 684587); Emma Sjöström, 'Shareholders as Norm Entrepreneurs for Corporate Social Responsibility' (2010) 94 Journal of Business Ethics, 177.

${ }^{115}$ Peter M. Haas, 'Do Regimes Matter? Epistemic Communities and Mediterranean Pollution Control'” (1989) 43 Int'l Org 377

${ }^{116}$ Jan Bebbington, Elizabeth A. Kirk and Carlos Larrinaga, 'The Production of Normativity: A Comparison of Reporting Regimes in Spain and the UK' (2012) 37 AOS 78

${ }^{117}$ See, for example, Bemelmans-Videc, M., Rist, R., \& Vegund, E. Carrots, Sticks \& Sermons: Policy Instruments \& Their Evaluations. (Transaction Publishers 1998); Nathaniel Keohane and Sheila Olmstead, Markets and the Environment. (Island Press 2007); National Research Council, New Tools for Environmental Protection: Education, Information and Voluntary Measures. (The National Academies Press 2002); Karen Palmer and MArgaret Walls, 'Using Information to Close the Energy Efficiency Gap: A Review of Benchmarking and Disclosure Ordinances' (2017) 10 Energy Efficiency 673. But see Robert B Cialdini, 'Crafting Normative Messages to Protect the Environment' (2003) 12(4) Current Directions in Psychological Science 105 118 Wagner (n 104).
} 
This is a draft chapter/article. The final version will be available in Planetary Boundaries and International Law edited by Duncan French and Louis Kotzé forthcoming 2020/21, Edward Elgar Publishing Ltd.

The material cannot be used for any other purpose without further permission of the publisher, and is for private use only.

of the planetary boundaries than have already been crossed and to remedy the harm that has already been done. 